\title{
Monetary Policy with Declining Deficits: Theory and an Application to Recent Argentine Monetary Policy
}

\author{
Rodolfo E. Manuelli and Juan I. Vizcaino
}

\begin{abstract}
The authors study the nature of the optimal monetary policy in a regime of fiscal dominance when the monetary authority - which can print money or issue interest-earning debt-is required to finance an exogenous sequence of transfers to the Treasury. They show that the degree of commitment on the part of the monetary authority has a significant impact on the details of the optimal policy. They apply this model to the recent experience of Argentina and find that the inflation rate experienced by Argentina during the first year of the monetary program is close to the predictions of a weakly time-consistent solution. Moreover, consistent with both versions of their model—full commitment and weak time consistency-the Central Bank of Argentina has increased the ratio of interest-earning debt relative to the monetary base. (JEL E52, E58, E61, E63, E65)
\end{abstract}

Federal Reserve Bank of St. Louis Review, Fourth Quarter 2017, 99(4), pp. 351-75. https://doi.org/10.20955/r.2017.351-375

n January 2016, the newly elected government of Argentina announced a policy of decreasing government budget deficits. It also specified what fraction of the deficit would have to be financed by the monetary authority. In the case of Argentina, this was a significant amount. For the year 2016, the Central Bank of Argentina (del Banco Central de la República Argentina, BCRA) was required to transfer to the Treasury approximately 2 percent of GDP out of a total government deficit of 4.8 percent of GDP. In addition, the BCRA decided to increase the monetary base by close to another 2.5 percent of GDP to increase the stock of foreign reserves.

The Argentine monetary authority finds itself in one of the versions of the economy that Sargent and Wallace (1981) studied in the well-known "Some Unpleasant Monetarist Arithmetic" paper-namely, the case in which the fiscal authority moves first and the monetary authority passively accommodates the fiscal demands. However, the problem faced by the BCRA differs from the problem studied by Sargent and Wallace in that the BCRA can issue interest-earning debt. Thus, the choice of monetary policy faced by the BCRA boils down to

Rodolfo E. Manuelli is a professor of economics at Washington University in St. Louis and a research fellow at the Federal Reserve Bank of St. Louis. Juan I. Vizcaino is a Ph.D. student at Washington University in St. Louis and a research associate at the Federal Reserve Bank of St. Louis. The authors thank Steve Williamson and two anonymous referees for their comments.

(c) 2017, Federal Reserve Bank of St. Louis. The views expressed in this article are those of the author(s) and do not necessarily reflect the views of the Federal Reserve System, the Board of Governors, or the regional Federal Reserve Banks. Articles may be reprinted, reproduced, published, distributed, displayed, and transmitted in their entirety if copyright notice, author name(s), and full citation are included. Abstracts, synopses, and other derivative works may be made only with prior written permission of the Federal Reserve Bank of St. Louis. 
the choice of the mix between debt and money, with the understanding that the only tax it can use to service the debt is the inflation tax. ${ }^{1}$

In this article, we study the policies that a monetary authority that is faced with such a temporary fiscal dominance situation-temporary in the sense that it is required to transfer a declining amount of resources to the fiscal authority-should pursue. In a very general sense, this is an optimal taxation problem and, like most problems of this type, the answer depends on the mix of taxes available and the degree of commitment on the part of the policymakers. In this particular application, the only tax available is the inflation tax, so the problem boils down to the choice of distortionary inflation taxes over time. One possibility is to allow the stock of money to be determined by the time path of the expenditures that the central bank must finance. Another option is to control the quantity of money in the economy by issuing interest-earning securities. This allows the central bank to choose the timing of increases in the money supply that need not match the timing of transfers.

We consider the case of a central bank that can issue its own interest-earning securities of a given maturity and that, in the language of Del Negro and Sims (2015), does not have fiscal support; that is, it cannot assume that the Treasury will recapitalize the bank with genuine resources if the bank incurs losses in its portfolio. Thus, the only option available to the central bank is to collect seigniorage to remain solvent. Unlike the Federal Reserve System, other central banks do issue actively tradable interest-earning bills of different maturities. ${ }^{2}$ Moreover, in many countries, they are held by both financial and non-financial institutions. According to Gray and Pongsaparn (2015), at least one-third of their sample of central banks issue their own interest-earning securities, with a median maturity of one month but with individual maturities as high as five years. $\frac{3}{}$

The second element of our study is the temporary nature of the expenditures that the central bank incurs. As with the case of interest-earning securities, there is no obvious analog of this situation in the United States, as the Fed is not required to make transfers to the Treasury. However, this possibility is common in emerging countries, as central bank financing is an important share of government revenue and the model applies to any temporary increase in spending. For example, it includes not only the situation in which the central bank is required to make temporary transfers to the Treasury but also the case in which the central bank responds to a banking crisis by increasing its liabilities to recapitalize financial institutions. $\underline{4}$

What is the optimal monetary policy (or, equivalently, optimal debt policy) for a central bank in the situation that we described above and given the available instruments? It turns out that the answer depends on the degree of commitment on the part of the monetary authority as well as on the details of the amount of resources that the monetary authority has to transfer to the fiscal authority, which we label "the deficit."

To make progress understanding optimal policies, we study a very simple economy in which the path of deficits and macro aggregates are known. This is similar to the economy that Uribe (2016) studies except that we investigate only the role of central bank financing of a given deficit.

We view the deficit as decreasing over time and eventually reaching zero. If the monetary authority can precommit to any policy, then a relatively standard optimal taxation argument, 
as described in Uribe (2016), implies that the central bank should use a mixture of monetary injections and debt to finance the required transfers. The basic idea is to smooth tax distortions - in this case, the distortions associated with the inflation tax-and to use interest-earning debt to finance the difference between the declining transfers and the revenue from the inflation tax. This is an extension of the tax-smoothing argument in Barro (1979) and the principles of financing of government spending in Lucas and Stokey (1983). The optimal policy is such that, even after the central bank is no longer required to finance a deficit, it chooses to inflate so that it can service the existing debt, and the present discounted value of the revenue from the inflation tax is equal to the present discounted value of the required transfers.

The assumption that the monetary authority is able to commit to positive inflation in the presence of zero deficits is somewhat problematic since the central bank has an incentive to implement a one-time open market operation issuing non-interest-earning money to buy the interest-earning debt. In the absence of commitment, and depending on the stock of debt, such an open market operation can potentially result in a jump in the price level, but it allows the monetary authority to implement a zero inflation policy from then on.

We label policies that impose that inflation be zero when the deficit is zero as weakly time-consistent policies. We show that weakly time-consistent policies impose tight restrictions on the amount of debt that can be issued. In particular, they imply that the total value of nominal assets relative to output cannot exceed the ratio of money to output under zero inflation. Our notion of weak time consistency amounts to requiring standard time consistency only when the fiscal situation is such that the monetary authority does not have to make any more transfers to the Treasury. As is well known in an economy with nominally denominated debt, a time-consistent policy is such that it engineers a large inflation as soon as possible to minimize the real value of the debt. We do not find such an extreme version of time consistency a useful way of thinking about policy, since it ignores other consequences of such an extreme policy. Thus, weak time consistency is a compromise that assumes that all economic participants-private sector and government alike- understand that the government will be restrictive about the policies that can be implemented in the future.

We use this model to study the optimal monetary policy for Argentina, taking as given the path of the deficit. We find that, consistent with both solutions, the Argentine monetary authority increased the debt-to-money ratio over the first year of the program. The key difference between the commitment and the weakly time-consistent solutions are the implications for the inflation rate. The commitment solution estimates an average inflation rate of 2.6 percent, while the weakly time-consistent solution predicts a value close to 25 percent. The recent Argentine experience-33 percent inflation in the first year of the program and a market expectation of 20 percent for the second year-appears to be much closer to the latter than to the former.

The work most closely related to ours - in addition to Uribe (2016) - is that by DíazGiménez et al. (2008), where it is also shown that time consistency limits the ability of the monetary authority to implement optimal policies. The key difference with our article is that the path of deficits is not decreasing and that there is coordination between the fiscal and monetary authorities, which implies that taxes other than the inflation tax are used to finance 
the service of the debt. Martin (2013) has a thorough discussion of optimal policies in economies with different frictions. He restricts himself to the case in which bonds have payoffs in real terms. In the context of New Keynesian models, Leeper, Campbell, and Ding (2016) discuss optimal monetary and debt policy imposing time consistency. For a recent survey of monetary models and optimal policies, see Canzoneri, Cumby, and Diba (2011).

There is a large literature that recognizes the fiscal dimension of monetary policy. See, for example, Bassetto and Messer (2013), Berriel and Bhattarai (2009), Cao (2017), and Del Negro and Sims (2015).

\section{MODEL}

We study the simplest economy that can be used to explore the role of lack of commitment. We take an off-the-shelf model similar to that used by Uribe (2016). We assume that output, $y$, and government spending, $g$, are constant. This implies that, in equilibrium, consumption is constant as well. The fiscal authority picks a sequence $\tau_{t}$ of taxes, and it demands from the monetary authority transfers $x_{t}=g-\tau_{t}$. We view $x_{t}$ as a decreasing function of time with the property that $x_{t}=0$ for all $t \geq T$.

It is convenient to separately describe the budget constraint for the monetary authority and the rest of the government (which we label "the Treasury"). $\frac{5}{}$

- The Treasury's budget constraint is

$$
\dot{B}_{t}^{T}+P_{t} x_{t}+P_{t} \tau_{t}=i_{t} B_{t}^{T}+P_{t} g
$$

where a dot over a variable indicates the time derivative. The income side of this constraint includes the sources of funds: bond issuance, $\dot{B}_{t}^{T}$; tax revenues, $P_{t} \tau_{t}$; and transfers from the monetary authority, $P_{t} x_{t}$. The expenditure side is the sum of interest payments, $i_{t} B_{t}^{T}$, and government purchases, $P_{t} g$.

- The monetary authority's budget constraint is

$$
\dot{M}_{t}+\dot{B}_{t}^{M}=i_{t} B_{t}^{M}+P_{t} x_{t}
$$

The expenditure side of this constraint includes transfers to the Treasury, $P_{t} x_{t}$, and interest payments on the debt it has issued, $i_{t} B_{t}^{M}$. The only sources of funds are increases in the money supply, $\dot{M}_{t}$-defined as the monetary base: currency in circulation plus non-interest-earning reserves-and interest-earning debt, $\dot{B}_{t}^{M}$.

- The notation makes it clear that in the economy under study there is interest-earning debt issued by the Treasury, $B_{t}^{T}$, which has to be distinguished from debt issued by the central bank, $B_{t}^{M}$, since the latter is backed only by future increases in the real value of the money stock (seigniorage) because we restrict $P_{t} x_{t}$ to be nonnegative.

- Putting together these two budget constraints, we arrive at the consolidated budgetary restriction for the government given by 


$$
\dot{M}_{t}+\dot{B}_{t}^{T}+\dot{B}_{t}^{M}+P_{t} \tau_{t}=i_{t}\left(B_{t}^{T}+B_{t}^{M}\right)+P_{t} g
$$

Given our focus in this article-the optimal choice by the monetary authority on how to finance the transfer $P_{t} x_{t}$-this consolidated budget constraint plays a minor role.

We assume that there is a representative dynasty that has preferences over consumption and real money balances given by

$$
U=\int_{0}^{\infty} e^{-\rho t}\left[u\left(c_{t}\right)+v\left(m_{t}\right)\right] d t
$$

where $c_{t}$ is consumption at time $t$ and $m_{t}=M_{t} / P_{t}$ is real money balances. $\underline{6}$ The functions $u$ and $v$ are assumed strictly concave and twice continuously differentiable. The private sector budget constraint is given by

$$
\dot{M}_{t}+\dot{B}_{t}^{T}+\dot{B}_{t}^{M}=i_{t}\left(B_{t}^{T}+B_{t}^{M}\right)+P_{t} y-P_{t} c-P_{t} \tau_{t} .
$$

On the income side, the representative dynasty earns interest at the nominal rate $i_{t}$ on its holdings of Treasury-issued debt, $B_{t}^{T}$, as well as the stock of monetary authority-issued debt, $B_{t}^{M}$. In addition, the representative agent earns income, spends resources purchasing consumption, and pays taxes (if $\tau_{t}<0$, the consumer receives a transfer).

In what follows, the key relationship is among real money balances, consumption, and the nominal interest rate. It can be shown that the representative agent's demand for real money balances satisfies

$$
\frac{v^{\prime}\left(m_{t}\right)}{u^{\prime}\left(c_{t}\right)}=i_{t},
$$

where

$$
m_{t}=\frac{M_{t}}{P_{t}}
$$

We assume that output is fixed and that government spending is constant. This implies that private consumption is constant and, hence, that the real interest rate is equal to the discount factor. In equilibrium, the interest rate is

$$
i_{t}=\rho+\pi_{t}
$$

which is the standard Fisherian result. The monetary authority understands the tradeoff between inflation and real money balances as captured by equation (1), which can be more conveniently written as

$$
\frac{v^{\prime}\left(m_{t}\right)}{u^{\prime}(c)}=\rho+\pi_{t} .
$$

As mentioned before, the budget constraint of the monetary authority (not the consolidated government budget constraint) is given by 


$$
\dot{M}_{t}+\dot{B}_{t}^{M}=i_{t} B_{t}^{M}+P_{t} x_{t}
$$

which in real terms is

$$
\dot{m}_{t}+\dot{b}_{t}^{M}=\rho b_{t}^{M}+x_{t}-\pi_{t} m_{t}
$$

where

$$
b_{t}^{M}=\frac{B_{t}^{M}}{P_{t}}
$$

and seigniorage is

$$
s_{t}=\dot{m}_{t}+\pi_{t} m_{t}
$$

\section{OPTIMAL MONETARY POLICY}

\section{Optimal Policy Under Full Commitment}

In this section we study the optimal monetary policy without imposing any restrictions on the monetary authority other than those required to satisfy the budget constraint in equilibrium. Since output (and consumption) are fixed, the optimal monetary policy is the solution to the following problem:

$$
\max _{\left\{b_{t}^{M}, m_{t}\right\}} \int_{0}^{\infty} e^{-\rho t} v\left(m_{t}\right) d t
$$

subject to

$$
\dot{m}_{t}+\dot{b}_{t}^{M}=\rho b_{t}^{M}+x_{t}-\left(\frac{v^{\prime}\left(m_{t}\right)}{u^{\prime}(c)}-\rho\right) m_{t}
$$

and the appropriate transversality condition. The optimal monetary policy (see Uribe, 2016) is summarized in the following result.

Proposition 1 (Optimal Policy Under Commitment [Uribe, 2016]). The optimal policy is characterized by a constant level of real money balances, $\mathrm{m}$, and a constant inflation rate, $\pi$, given by

$$
\pi=\frac{v^{\prime}(m)}{u^{\prime}(c)}-\rho
$$

where $\mathrm{m}$ is chosen so that

$$
\int_{0}^{\infty} e^{-\rho t}\left[\frac{v^{\prime}(m)}{u^{\prime}(c)} m-x_{t}\right] d t=b_{0}^{M}+\bar{m}_{0}
$$

and a debt policy given by

$$
b_{t}^{M}=e^{\rho t}\left(\int_{0}^{t} e^{-\rho s}\left[x_{s}-\left(\frac{v^{\prime}(m)}{u^{\prime}(c)}-\rho\right) m\right] d s+b_{0}^{M}+\bar{m}_{0}-m\right) .
$$

(See the appendix.) 
Under the optimal policy with commitment, inflation is constant and the stock of debt initially increases and then decreases and it converges to zero as $t \rightarrow \infty$.

\section{Weakly Time-Consistent Optimal Policy}

The optimal policy with commitment is such that, after time $T$, the inflation tax is used to finance repayment of principal and interest on the debt issued by the monetary authority. This policy is not weakly time consistent. To see this, consider what happens at time $T$. Let the stock of money at that time be denoted $M_{T}$ and the stock of bonds (in nominal terms) $B_{T}^{M}$. The problem faced by the central bank is to choose monetary policy to solve the continuation problem. Formally, the problem is

$$
\max _{\left\{b_{t}^{M}, m_{t}\right\}} \int_{T}^{\infty} e^{-\rho(t-T)} v\left(m_{t}\right) d t
$$

subject to equation (4), which is

$$
\dot{m}_{t}+\dot{b}_{t}^{M}=\rho b_{t}^{M}+x_{t}-\left(\frac{v^{\prime}\left(m_{t}\right)}{u^{\prime}(c)}-\rho\right) m_{t},
$$

and subject to a given initial amount of total liabilities of the central bank, $M_{T}+B_{T}$.

Proposition 2 (Optimal Policy After Time T). Assume that the central bank cannot issue negative debt; then the optimal monetary policy engineers an open market operation so that the resulting stocks of money and bonds are

$$
M_{T}^{\prime}=M_{T}+B_{T}
$$

and the price level is

$$
P_{T}=\frac{M_{T}^{\prime}}{m^{*}}
$$

where $\mathrm{m}^{*}$ is such that the optimal inflation rate is zero; that is,

$$
\frac{v^{\prime}\left(m^{*}\right)}{u^{\prime}(c)}=\rho \text {. }
$$

(See the appendix.)

When the central bank is not required to finance any more deficits, there is no longer any optimal taxation argument that requires any smoothing of distortions over time and the economy reverts to the (constrained) first best. The optimal monetary policy solves a finitehorizon version of the previous problem, with the additional terminal condition that the stock of central bank liabilities at time $T$ must be equal to the level of real money balances under zero inflation. This condition amounts to a restriction that the price level cannot jump at time $T$. This is one of the principles of honest government as defined by Auernheimer (1974). 
The problem faced by the monetary authority is given by

$$
\max _{\left\{m_{t}\right\}} \int_{0}^{T} e^{-\rho t} v\left(m_{t}\right) d t
$$

subject to

$$
\dot{b}_{t}^{M}=\rho b_{t}^{M}+x_{t}-\left(\frac{v^{\prime}\left(m_{t}\right)}{u^{\prime}(c)}-\rho\right) m_{t}
$$

and subject to

$$
m_{T}+b_{T}^{M}=m^{*}
$$

Proposition 3 (Optimal Policy until T). The optimal policy is such that real money balances are constant and they satisfy

$$
\frac{v^{\prime}(m) m}{u^{\prime}(c)}=\frac{\rho}{1-e^{-\rho T}}\left[\left(\bar{m}_{0}+b_{0}^{M}\right)+\int_{0}^{T} e^{-\rho t} x_{t} d t-e^{-\rho T} m^{*}\right] .
$$

(See the appendix.)

Let $R_{t}$ be the ratio of interest earnings bonds to real money balances. Thus,

$$
R_{t}=\frac{b_{t}^{M}}{m_{t}}
$$

Given that the optimal level of real money balances is $m$, it follows that

$$
R_{t}=\frac{e^{\rho t}\left[\left(\bar{m}_{0}+b_{0}^{M}\right)+\int_{0}^{t} e^{-\rho s}\left(x_{s}-\left(\frac{v^{\prime}(m)}{u^{\prime}(c)}\right) m\right) d s\right]}{m} .
$$

Since we are interested in the case in which deficits are declining, the term

$$
\left(x_{s}-\left(\frac{v^{\prime}(m)}{u^{\prime}(c)}\right) m\right)
$$

is initially positive and turns negative as $t \rightarrow T$. Thus, $R_{t}$ is initially increasing and then decreasing.

Inflation is given by

$$
\pi=\left(\frac{v^{\prime}(m)}{u^{\prime}(c)}-\rho\right)
$$

which is decreasing in real money balances.

The key implication of the weak time-consistency requirement is that the value of the stock of liabilities of the monetary authority cannot exceed the level of the demand for money under zero inflation. 


\section{ARGENTINE MONETARY POLICY THROUGH THE LENS OF THE MODEL}

In this section, we briefly describe the recent monetary policy followed by the BCRA, calibrate the model, and study the implications under both commitment and weak time consistency for the Argentine experience.

\section{Recent Argentine Monetary Policy}

The Institutional Framework. The BCRA's charter specifies that its mission is "to promotewithin the framework of its powers and the policies set by the National Government-monetary and financial stability, employment, and economic development with social equality" (BCRA n.d.; emphasis added). .7 The BCRA board — including its president and vice presidentsis appointed by the executive branch with Senate agreement, and it can be removed by the branch if a special commission of Congress agrees. In practice, it has not been difficult for the branch to replace the authorities of the central bank and, for practical purposes, the BCRA is not independent. $\underline{8}$

The BCRA issues interest-earning securities-as of this writing the only type is denominated Lebacs (Letras del Banco Central) - with maturities that range from 28 to 273 days. These central bank bills and repos are used to conduct open market operations to regulate the quantity of money. The BCRA also operates a discount window and manages the reserves of foreign currency.

When the Argentine monetary authority transfers resources to the Treasury, it increases the liability side of its balance sheet by the amount of the transfers (an increase in the monetary base) and, simultaneously, it increases the asset side by viewing the transfer as a loan labeled "transitory advances." According to current legislation, these transitory advances are capped at the max of 12 percent of the monetary base or 10 percent of annual government revenue. These loans have a duration of a year, but continuous increases in the monetary base allow for indefinite renewals and increases in the stock. In fact, they are never repaid. $\stackrel{9}{\text { Since }}$ the BCRA has the ability to issue its own interest-earning debt, it can conduct an open market operation in this security - conduct an auction — to absorb some or all of the increase in the money supply.

To illustrate the mechanism, consider the following example: Suppose the BCRA wants to make a one-time transfer to the Treasury in the amount $Z$. This creates an increase in the liability side of its balance sheet (an increase in the monetary base) equal to $Z$. On the asset side, the transitory advances account is increased by $Z$. If the central bank does not want to change the money supply, this would be the end of the story.

Consider now the case in which the central bank-for whatever reason-decides that the monetary base should be only $Z / 2$. Then, to absorb liquidity, it auctions off interest-earning securities in the amount $Z / 2$. After a period-say, a year-the central bank increases the money supply to pay off the interest-earning bills. Thus, after one period, the money supply-and the liabilities of the central bank-equals $Z+(Z / 2) \times i$. On the asset side, it is standard for the central bank to give the rest of the government a new loan in the amount $Z$. Thus, the 
transitory-advances account still has a balance equal to $Z$. Since the BCRA has funded this investment in a zero-interest government loan with a mix of money (that pays no interest) and central bank bills (that earn a positive interest), the result is an operational loss. This loss reduces bank capital and has to be compensated for somehow. The details of how this is done vary across the world. In some cases, central banks simply activate losses. In other cases, the Treasury issues a non-negotiable zero-interest long-duration (e.g., over 50 years) bond that is used to recapitalize the bank. $\frac{10}{10}$ In the case of Argentina, the BCRA also has foreign exchange reserves among its assets, and it revalues them according to standard accounting practices. This creates a paper profit that has sufficed to compensate for the losses on the BCRA's investment portfolio.

\section{Recent Developments}

Even though a discussion of the monetary policy of Argentina is beyond the scope of this article, $\underline{11}$ it is useful to document the magnitude of the transfers that the BCRA has made (and continues to make) to the Treasury. In terms of the model described before, the transfer corresponds to what we labeled $P_{t} x_{t}$. The size of the transfers since 2004 is shown in Table 1.

In the past few years, BCRA financing of deficits has been very large. The source of this financing has been twofold. First, in the period until 2010-15, about half of the transfers were financed by selling assets. Basically, the BCRA used part of its stock of foreign currency reserves to finance the Treasury. The other half consisted of transfers.

This policy has resulted in generally high and variable inflation. Figure 1 shows the relationship between inflation and seigniorage for the period 2004-16. $\underline{12}$

Although the traditional Laffer-curve-type pattern $\underline{13}$ does not emerge for the sample period under study, the resources obtained via seigniorage are clearly non-negligible, averaging 2 percent of GDP, for an average annualized inflation rate close to 21 percent. The figure shows a relatively high degree of instability in the demand for money, which implies that the same inflation rate is associated with a wide range of seigniorage values.

The more recent monetary experience is summarized in Table 2. The base of the inflation tax-the monetary base-fluctuates around 8 percent of GDP, while in the recent past inflation has averaged about 33 percent. 14 This implies that revenue from seigniorage has been approximately 2 percent of GDP. As mentioned before, during the year 2016, the BCRA transferred to the Treasury approximately 2 percent of GDP and purchased foreign currency reserves amounting to 2.6 percent of GDP. $\underline{15}$ 
Figure 1

Inflation and Seigniorage in Argentina (2004-16)

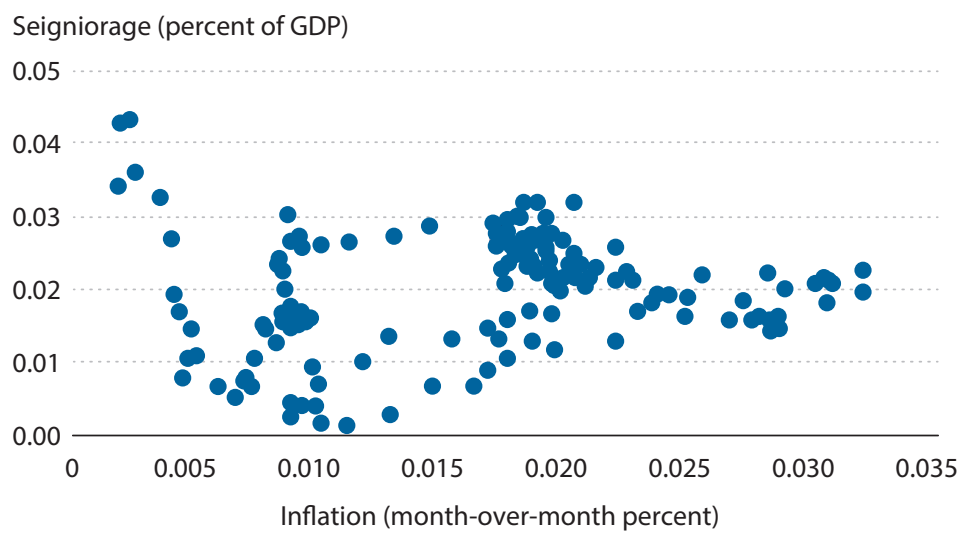

SOURCE: BCRA, Instituto Nacional de Estadística y Censos, and provincial statistical institutes.

\section{Table 2}

Money and Inflation

\begin{tabular}{|c|c|c|c|c|c|c|c|c|}
\hline \multirow[b]{2}{*}{ Concept } & \multicolumn{4}{|c|}{2015} & \multicolumn{4}{|c|}{2016} \\
\hline & Q1 & Q2 & Q3 & Q4 & Q1 & Q2 & Q3 & Q4 \\
\hline$M / Y$ & 0.09 & 0.08 & 0.09 & 0.09 & 0.08 & 0.07 & 0.08 & 0.08 \\
\hline$B / M$ & 0.56 & 0.85 & 0.54 & 0.47 & 0.67 & 0.79 & 0.82 & 0.89 \\
\hline Inflation & 0.25 & 0.27 & 0.27 & 0.34 & 0.57 & 0.31 & 0.24 & 0.20 \\
\hline
\end{tabular}

NOTE: $M / Y$, money-to-output ratio. B/M, BCRA's debt-to-output ratio.

SOURCE: BCRA, Instituto Nacional de Estadística y Censos, and provincial statistical institutes.

Over the past year, the BCRA has been increasingly relying on interest-earning debt as an alternative to outright increases in the monetary base. Table 2 shows that there has been an increase in the ratio of central bank debt to money over the past two years and, in particular, since the beginning of the new monetary program in 2016. During 2016, the ratio of interestearning debt to the monetary base has increased from 67 percent to almost 90 percent.

We now develop a quantitative version of the model that is suitable for studying optimal monetary policy in the context of the Argentine situation.

\section{Theoretical Restrictions}

We assume that

$$
v(m)=z \frac{(m y)^{1-\gamma}}{1-\gamma}, u(c)=\frac{(c y+a y)^{1-\gamma}}{1-\gamma},
$$


where $m$ is money demand relative to output and $c$ is the ratio of consumption to output, while $\alpha$ is a preference shifter that captures minimal levels of consumption. $\frac{16}{}$ Following Lucas and Nicolini (2013), we take that the relevant concept of transactions demand for money is M1.

The demand for money, $m$, satisfies

$$
m=(c+\alpha)(z i)^{-1 / \gamma}
$$

This specification implies that seigniorage is given by

$$
s(m)=\left[z\left(\frac{m_{1}}{c+\alpha}\right)^{-\gamma}-r\right] m_{0},
$$

where $m_{0}$ is the monetary base (the base of the inflation tax). If the ratio of $m_{1} / m_{0}$ is denoted $1+\zeta$, then define

$$
K \equiv z\left(\frac{1+\zeta}{c+\alpha}\right)^{-\gamma}
$$

With this notation, seigniorage is

$$
s(m)=\left[K(m)^{-\gamma}-r\right] m,
$$

where from now on $m$ denotes the stock of the monetary base. Since we use seigniorage to estimate the relevant parameters, it is clear that we can only identify $K$ and not its individual components.

For the time path of the deficit, we assume the following functional form:

$$
x_{t}=\left\{\begin{array}{ll}
\psi_{0}-\psi_{1} t e^{-\kappa(T-t)} & t \leq T \\
0 & t>T
\end{array} .\right.
$$

Let

$$
\hat{x}=\int_{0}^{T} e^{-\rho t} x_{t} d t
$$

Given our choice of functional forms, the optimal level of money balances in the commitment case, $m_{c}$, is the solution to

$$
K m_{c}^{1-\gamma}=\rho\left(w_{0}+\hat{x}\right)
$$

From Proposition 3, real money balances under weak time consistency, $m_{w}$, satisfy

$$
K m_{w}^{1-\gamma}=\frac{\rho}{1-e^{-\rho T}}\left(w_{0}+\hat{x}-e^{-\rho T} m^{*}\right),
$$

where $m^{*}$ is the solution to

$$
K\left(m^{*}\right)^{-\gamma}=\rho
$$


The level of real money balances under the weakly time-consistent solution is

$$
m_{w}=\left[\frac{\rho}{K\left(1-e^{-\rho T}\right)}\left(w_{0}+\hat{x}-e^{-\rho T}\left(\frac{K}{\rho}\right)^{1 / \gamma}\right)\right]^{\frac{1}{1-\gamma}},
$$

the implied inflation rate is

$$
\pi_{w}=\frac{K}{m_{w}^{\gamma}}-\rho,
$$

and the ratio of the two inflation rates is

$$
\frac{\pi_{w}}{\pi_{c}}=\left[\frac{w_{0}+\hat{x}-e^{-\rho T}\left(\frac{K}{\rho}\right)^{1 / \gamma}}{\left(1-e^{-\rho T}\right)\left(w_{0}+\hat{x}\right)}\right]^{\frac{\gamma}{\gamma-1}} .
$$

To summarize, the optimal level of real money balances in the commitment and weakly time-consistent versions of the optimal monetary policy solve equations (5) and (6), respectively.

From a qualitative perspective, increases in the present value of central bank liabilities, $w_{0}+\hat{x}$, not only increase the inflation rates in each of the two scenarios (as more seigniorage is needed to finance the interest on the liabilities of the monetary authority) but also increase the gap between the inflation rates in the commitment and weakly time-consistent solutions. An increase in the demand for money, as measured by an increase in $K$, decreases inflation in both regimes, but more so in the weakly time-consistent case, as it lifts up the demand for real money balances under zero inflation..$^{17}$ Finally, increases in the time horizon reduce $\pi_{w} / \pi_{c}$.

\section{Calibration}

We use monthly data $\frac{18}{10}$ to estimate the following regression by nonlinear least squares (NLLS):

$$
s_{t}=\left[K m_{t}^{-\gamma}-r\right] \times m_{t}+\varepsilon_{t},
$$

where $s_{t}$ is seigniorage in period $t$, defined as the change in the monetary base relative to the flow of output; $m_{t}$ is the monetary base; and $\varepsilon_{t}$ is an error term. We assume that $r=\rho=0.04$.

Since monetary policy in Argentina has been extremely variable with long periods in which financial institutions were forced to hold reserves in relatively large proportions, we use monthly data for 2005-15, a period with a relatively more stable monetary policy regime. One major disadvantage of using monthly data for Argentina (see Burdisso, Blanco, and Sardi, 2010) is that seasonal fluctuations are large. In our model, these seasonal fluctuations translate directly into seasonal changes in the seigniorage. We address this issue by seasonally adjust- 
Figure 2

Time Path of the Deficit

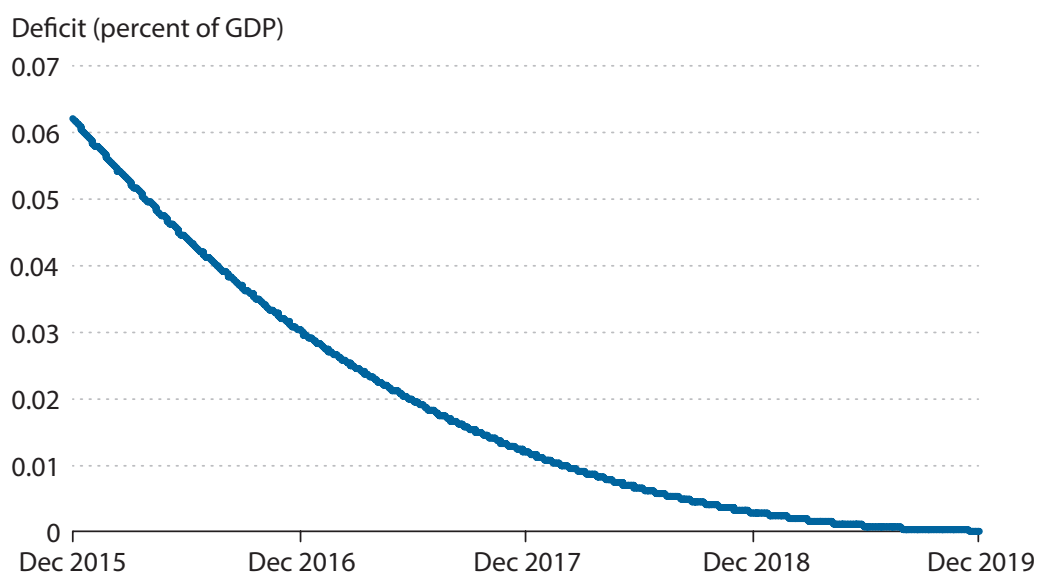

SOURCE: Authors' calculations.

ing both the seigniorage and the real money balances series. For our purpose, the critical coefficient to estimate is $\gamma$. Our estimated value is $\gamma=3$, with a robust standard error equal to (1.3). $\underline{19}$ This implies that the semi-elasticity of the demand for money is -0.33 .

The literature has not arrived at a consensus value for the semi-elasticity of the demand for money with respect to the interest rate. The estimates of Mogliani, Urga, and Winograd (2009), Gay (2005), and Basco, D'Amoto, and Garegnani (2012) suggest a value between -1.24 and -2.79 . Kiguel and Neumeyer (1995) find a much lower elasticity equal to -0.05 . Uribe (2016) uses the Kiguel and Neumeyer (1995) results to estimate a semi-elasticity of -0.13 . Our estimate is on the low side but not out of line with other estimates of the demand for money as reported in Canzoneri, Cumby, and Diba (2011). 20

Finally, to pin down the scale parameter $K$, we use average real money balances relative to output during the year $2015(m=0.086)$ and the nominal interest rate on time deposits $(i=0.22)$. The estimate is

$$
K=i \times m^{\gamma}=0.00014
$$

This implies that real money balances under zero inflation (relative to output) equal 0.15 , a large but not unreasonable value.

We now describe how we select the parameters for the time path of the deficit. First, since we assume that the deficit is zero in $T=4$, it follows that

$$
\psi_{0}-\psi_{1} \times 4=0
$$


Figure 3

\section{Commitment: Debt-to-Monetary Base Ratio}

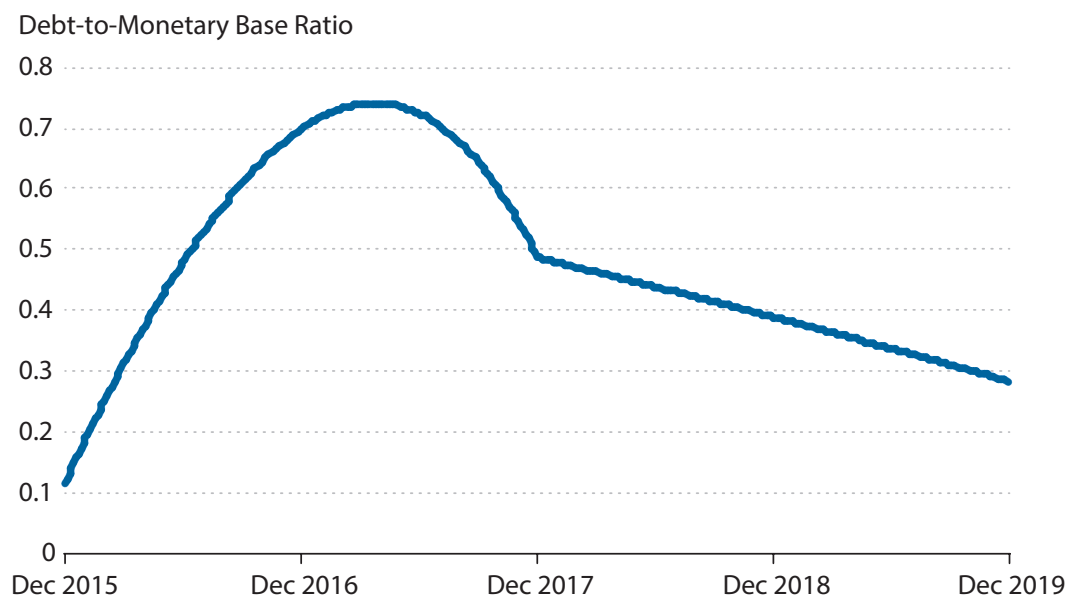

SOURCE: Authors' calculations.

To calibrate the other two parameters $\left(\kappa, \psi_{1}\right)$, we assume that the average deficit during the first year of the program is 4.6 percent of GDP and during the second year is 2 percent of output. The value that we assume for the first year is based on an estimate of the transfer the BCRA agreed to give to the Treasury (about 2 percent of output) and the increase in the stock of foreign reserves (which amounts to 2.6 percent of GDP). $\stackrel{21,22}{2}$ Thus, $\kappa, \psi_{1}$ solve

$$
\begin{aligned}
\psi_{1} \times \frac{\left(4+\left(4-e^{-3 \kappa}\right)\right.}{2} & =0.046 \\
\psi_{1} \times \frac{\left(4-e^{-3 \kappa}+4-2 e^{-2 \kappa}\right)}{2} & =0.020 .
\end{aligned}
$$

The solution is $\kappa=-0.24$ and $\psi_{1}=0.0155$. Given our estimates, the present discounted value of the deficit-which we denoted $\hat{x}$ in the previous section-is 6.9 percent of GDP. $\underline{23}$

Taking December 2015 as the starting point, the path of the deficit is shown in Figure 2.

As required by the theory, we impose that the initial value of the liabilities of the central bank equal the existing stock in December 2015, which was approximately 14 percent of output.

\section{Implications of the Model and the Experience of Argentina}

Our quantitative model implies that in the full commitment case, the monetary base is about 13 percent of output and the average annual inflation rate is 2.6 percent. The debt of the central bank increases monotonically until mid-2018. The initial value is 1.5 percent of GDP in December 2015; it reaches a maximum of 9.5 percent of GDP by mid-2018. In order to better compare with the situation in Argentina, Figure 3 displays the time path of the ratio of central bank debt relative to the (constant under the optimal policy) monetary base. 


\section{Figure 4}

\section{Weak Time Consistency: Debt-to-Monetary Base Ratio}

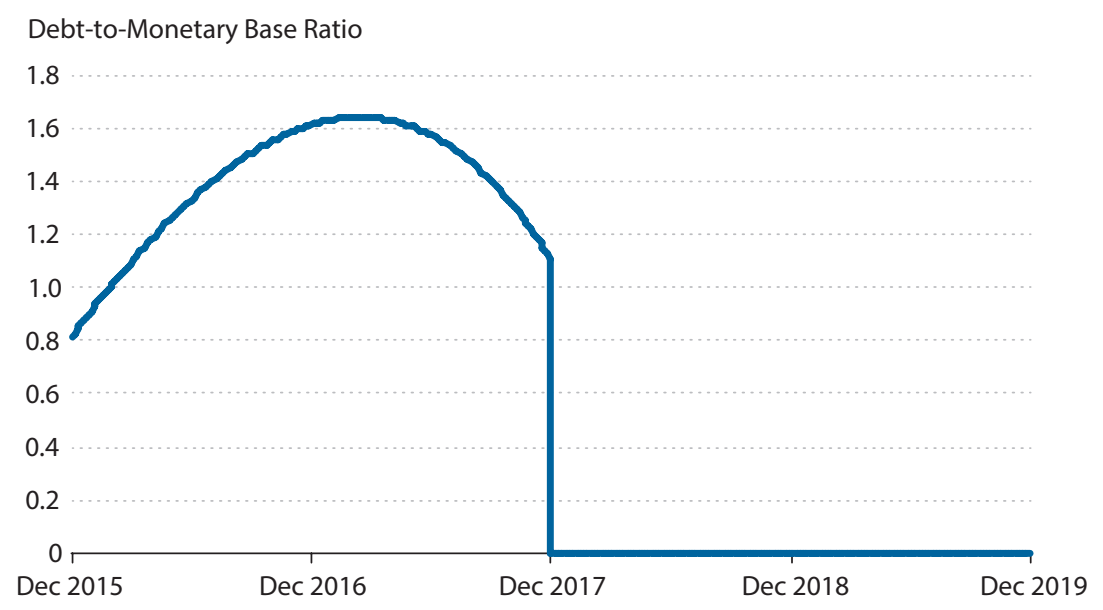

SOURCE: Authors' calculations.

The debt-to-monetary base ratio increases from its initial level of around 0.12 up to around 0.75 by mid- 2017 and starts decreasing afterward.

What is the optimal policy if the monetary authority cannot precommit to positive inflation with zero deficits? In this case (weak time consistency), the optimal level of the monetary base is lower than under full commitment and equals 7.9 percent of output. The consequence is a much higher average inflation of 24.7 percent.

Weak time consistency implies that the optimal policy is to retire the debt-the only option if revenue from inflation is going to be zero- at the end of the positive deficit period. Thus, the optimal policy calls for a large open market operation at time $T$. The time path of the debt-to-monetary base ratio is displayed in Figure 4.

This version of the optimal policy implies that in mid-2017 the debt-to-monetary base ratio peaks at about 160 percent, significantly higher that under the full-commitment solution.

How should one evaluate the recent monetary policy of the BCRA in light of the optimal monetary policy the model prescribes given the fiscal dominance regime in Argentina? Based on the model, Argentine monetary policy has not been optimal. The model predicts-for both the commitment and the weakly time-consistent solutions-that inflation must be constant over the period of the program. The inflation rate in Argentina during the first year was decreasing. However, it is interesting to explore which of the two scenarios (commitment or weak time consistency) more closely resembles the Argentine experience during 2016. To this end, we consider two indicators: (i) the ratio of interest-earning debt to money and (ii) the inflation rate.

The intuition from the optimal taxation exercise is that the BCRA should be using debt increasingly during this period for two related reasons. First, the deficit is viewed only as tem- 
porary. Second, because of the decision to increase the stock of foreign reserves during 2016, it is frontloaded. Both versions of the model-commitment and weak time consistency-prescribe that the debt-to-money ratio should have increased during 2016. This is consistent with the evidence. The quantitative model implies that the debt-to-money ratio at the end of the first year of the program should be between 47 percent (under commitment) and 133 percent (if the policy is weakly time consistent). The corresponding value for Argentina is 89 percent, roughly in the middle of the two estimates. Given the simplicity of the model, it does not seem that using this indicator can determine the degree of commitment implicit in the recent policy.

The two versions of the model differ significantly in terms of their implications for the inflation rate. Under commitment, the inflation rate is estimated to be less than 3 percent (average for the duration of the program), while the weakly time-consistent solution estimates inflation to be much higher, close to 25 percent. The recent Argentine experience seems to be much closer to the latter. As mentioned before, the inflation rate during the first year of the program was 33 percent and the market expectations for the second year are around 20 percent. $\underline{24}$ Even if the BCRA succeeds in significantly lowering inflation during the rest of the program, it appears that the actual policy is better approximated by the weakly time-consistent solution.

In a recent paper, Uribe (2016) uses a similar model to analyze the Argentine experience. He studies only the full-commitment solution and includes in his analysis a much larger class of government debt, as he is interested in how to finance the overall deficit and not just the fraction that must be financed by the central bank. $\frac{25}{2}$ His estimates of the demand for money are different from ours, as he assumes that semi-elasticity with respect to the interest rate is significantly lower than ours. He concludes that the inflation rate associated with the optimal policy is slightly below 5 percent and the consolidated government's debt-to-GDP ratio peaks above 40 percent.

We view the more limited scope of our analysis that includes only the liabilities of the central bank as a more appropriate use of the model. A comparison with the evidence suggests that this is the case.

At the end of 2016, the total liabilities of the BCRA amounted to 16.2 percent of GDP. Given our estimate of the present value of the deficit for the remaining three years of the program $-\hat{x}$ for the continuation is 2.6 percent of output-the weakly time-consistent version of the model implies that the average inflation rate will be close to 18 percent. There are two forces that influence the inflation estimate. On the one hand, the present discounted value of the deficit is substantially smaller ( 2.6 percent vs. 6.9 percent), reflecting the frontloaded path of the deficit. This reduces required inflation. On the other hand, the stock of liabilities is higher (16.2 percent vs. 14 percent), and this requires a higher inflation rate. In a sense, our estimate is consistent with the view that inflation should be decreasing in Argentina butviewed as an average over the life of the program - it is higher than the official forecasts. $\underline{26}$

\section{CONCLUDING COMMENTS}

This article shows that the quantitative implications of the optimal monetary policy under fiscal dominance depend on the assumed ability of the monetary authority to commit. Under 
full commitment, a standard optimal taxation argument shows that the monetary authority should issue both bonds and money. When the central bank cannot commit to a policy of positive inflation when the deficit is zero, then the ability to smooth the distortion associated with the inflation tax is reduced and there is a tight cap associated with the maximum amount of debt that the monetary authority can issue.

The model, calibrated to capture the basic details of the recent monetary policy of Argentina, implies that the Argentine monetary authority has followed a policy that, to a first rough approximation, results in an inflation rate that is close to that implied by the optimal policy under weak commitment. However, the actual policy deviates from the optimal in that the inflation rate is not constant.

To what extent do the issues we discussed in this article apply to the United States? It is important to note the differences in institutional setups between the type of central bank that we analyzed - the Central Bank of Argentina - and the Federal Reserve System. First, and most important, the Federal Reserve System is truly independent and, therefore, it does not have to agree to finance the rest of the government at a pre-specified level. ${ }^{27}$ Second, the Fed does not issue longer-term interest-earning securities and, hence, does not face the prospect of raising seigniorage to service the debt. $\underline{28}$

Are there lessons for the conduct of monetary policy in the United States that can be drawn from this exercise? The answer is a qualified yes. The Fed, just like the BCRA, can issue a security-remunerated reserves-that can be used to drain liquidity from the system. Are there possible scenarios that the Fed could face that resemble the one analyzed in this article? Ignoring some legal issues, the Fed could find itself in a situation in which it has to transfer resources to the financial system, for example, during a banking crisis. In this case, the Fed can choose to increase the money supply in the form of non-interest bearing reserves-to absorb part of the increase by paying interest on some portion of total reserves. This would come close to issuing interest-earning securities to partially absorb excess liquidity. This type of arrangement is different from the current situation in which all reserves receive the same return. We view creating two types of reserves as the simplest way of creating a bond that, in this example, would be held only by financial institutions.

There is a sense in which the activities of the Fed since 2008, when it increased its holdings of assets, could fit in this framework. Ignoring for now the quality of the assets in the Fed's portfolio (that were mostly high-quality mortgage-backed securities and Treasuries), one could argue that the ideas we discussed in this article might apply to a central bank that acquires private sector assets if, subsequently, the market value of those assets drops significantly. In that case, the situation is analogous to the Fed making a one-time transfer to the private sector, which is close to what we discussed. 


\section{APPENDIX}

\section{Proofs}

Proof of Proposition 1. The Hamiltonian of the problem is

$$
H^{C}=v(m)+\lambda_{m}\left[\rho b^{M}+x-\left(\frac{v^{\prime}(m)}{u^{\prime}(c)}-\rho\right) m-z\right]+\lambda_{b}(z),
$$

where as a matter of notation we define

$$
\dot{b}^{M}=z
$$

The first-order conditions associated with the maximum problem are

$$
\begin{aligned}
& \lambda_{m}=\lambda_{b} \\
& \dot{\lambda}_{m}=\rho \lambda_{m}-v^{\prime}(m)+\lambda_{m}\left[\frac{v^{\prime}(m)}{u^{\prime}(c)}-\rho-\frac{m v^{\prime \prime}(m)}{u^{\prime}(c)}\right] \\
& \dot{\lambda}_{b}=\rho \lambda_{b}-\rho \lambda_{m} .
\end{aligned}
$$

It follows that $\dot{\lambda}_{b}=\dot{\lambda}_{m}=0$ and real money balances are given by

$$
v^{\prime}(m)=\lambda_{m}\left[\frac{v^{\prime}(m)}{u^{\prime}(c)}-\frac{m v^{\prime \prime}(m)}{u^{\prime}(c)}\right] .
$$

Thus, real money balances and the inflation rate are constant. The government budget constraint implies that the real stock of central bank debt evolves according to

$$
\dot{b}_{t}^{M}=\rho b_{t}^{M}+x_{t}-\left(\frac{v^{\prime}(m)}{u^{\prime}(c)}-\rho\right) m
$$

and the solution that satisfies the transversality condition is such that

$$
b_{t}^{M}=e^{\rho t}\left(\int_{0}^{t} e^{-\rho s}\left[x_{s}-\left(\frac{v^{\prime}(m)}{u^{\prime}(c)}-\rho\right) m\right] d s+\left(b_{0}^{M}+m_{0}\right)-m\right) .
$$

In particular, the amount of debt issued by the monetary authority at $t=0$ is

$$
\int_{0}^{\infty} e^{-\rho t}\left[\left(\frac{v^{\prime}(m)}{u^{\prime}(c)}-\rho\right) m-x_{t}\right] d t=b_{0}^{M}+\bar{m}_{0} .
$$


Proof of Proposition 2. The Hamiltonian for the central bank's maximization problem is

$$
H^{P}=v(m)+\lambda_{m}\left[\rho b^{M}+x-\left(\frac{v^{\prime}(m)}{u^{\prime}(c)}-\rho\right) m-z\right]+\lambda_{b}(z),
$$

which is similar to the one for the commitment case. The same argument then shows that real money balances are constant and, under the policy that monetized the debt, inflation can be chosen so that

$$
\int_{T}^{\infty} e^{-\rho(t-T)}\left[\left(\frac{v^{\prime}(m)}{u^{\prime}(c)}-\rho\right) m-x_{t}\right] d t=0,
$$

but since $x_{t}=0$ for all $t \geq T$, then $m=m^{*}$.

Proof of Proposition 3. An argument similar to the previous proposition shows that the optimal $m$ is constant. Then central bank debt is given by

$$
b_{t}^{M}+m=e^{\rho t}\left[\left(\bar{m}_{0}+b_{0}^{M}\right)+\int_{0}^{t} e^{-\rho s}\left(x_{s}-\left(\frac{v^{\prime}(m)}{u^{\prime}(c)}\right) m\right) d s\right] .
$$

Imposing the terminal condition $m_{T}+b_{T}^{M}=m^{*}$, we get the result.

\section{Estimation}

One issue with nonlinear least-squares estimation is that, in some cases, estimates are very sensitive to the initially chosen parameters. For the estimation procedure, we provide an initial value for the money demand shifter $K$ consistent with the average real money balances relative to output during the year $2015(m=0.086)$ and the nominal interest rate on time deposits $(i=0.22)$. We obtain $K=0.00014$. In the case of $\gamma$, we provide as an initialization point a set of values in the ranges suggested by the money-demand estimation literature (from 0.5 to 20 ).

In all cases, we obtain $K=0.00018(0.000585)$ and $\gamma=2.97(1.32)$, where the heteroskedasticity- and autocorrelation-consistent standard errors are reported in parentheses. Although the estimate for $K$ is not statistically significant, a joint significance test suggests that the estimated coefficients are statistically significant at the 1 percent level. For the quantitative simulation, given that for $K$ the confidence interval of the estimation suggests a wide range of possible values, we calibrate it in such a way so that it matches its average value for 2015 . 


\section{Estimates of the Demand for Money}

There are a number of estimates of the demand for money in Argentina. The different estimates vary in terms of their coverage, the notion of money, and how they handle dynamic adjustment. These are the results from a cursory review of the literature:

1. Mogliani, Urga, and Winograd (2009) find the following: In their estimation of the long-run demand for money allowing for structural breaks (and using M1 as the notion of money), real money balances display a unit elasticity with respect to income, while the semi-elasticity with respect to the interest rate is -1.6 .

2. Kiguel and Neumeyer (1995) define money as M1 and also estimate the demand for money in different subperiods. They find that the coefficient of income is not significantly different from zero, and their estimates of the semi-elasticity with respect to the interest rate range from -0.02 to -0.05 .

3. Gay (2005) estimates the demand for money (but does not say what he means by money) and he uses as his right-hand-side variable $\ln \left(i_{t} /\left(1+i_{t}\right)\right)$. To turn his estimate into a semi-elasticity requires taking a stand on the value of $i_{t}$. If Gay's estimated coefficient is denoted $\beta$, then the semi-elasticity is

$$
\frac{\beta}{\left(1+i_{t}\right) i_{t}}
$$

If we assume that $i_{t}=0.1$, then the resulting semi-elasticity is (taking an average of his estimates) -2.79 , while if the interest rate is 20 percent $\left(i_{t}=0.2\right)$ the estimate is -1.24 .

4. Basco, D'Amoto, and Garegnani (2012) estimate that the income elasticity of the demand for money is slightly above 1 (although it is not clear whether it can be rejected that it is equal to 1 ) and the interest semi-elasticity is -1.8 .

It is not surprising that since Argentine monetary policy has been very unstable over the last half century, with several episodes of hyperinflation, it is not possible to find robust estimates of the demand for money. In this article, we use some information about the semielasticity of the demand for money from the existing studies and complement it with a very simple statistical model to obtain a reasonable parameterization of the relevant functions that allows us to make progress in understanding the recent experience. 


\section{The Evolution of Debt Levels}

Here we report the implications of the two versions of the model for the ratio of central bank debt to GDP.

\section{Figure A1}

\section{Commitment: Debt-to-GDP Ratio}

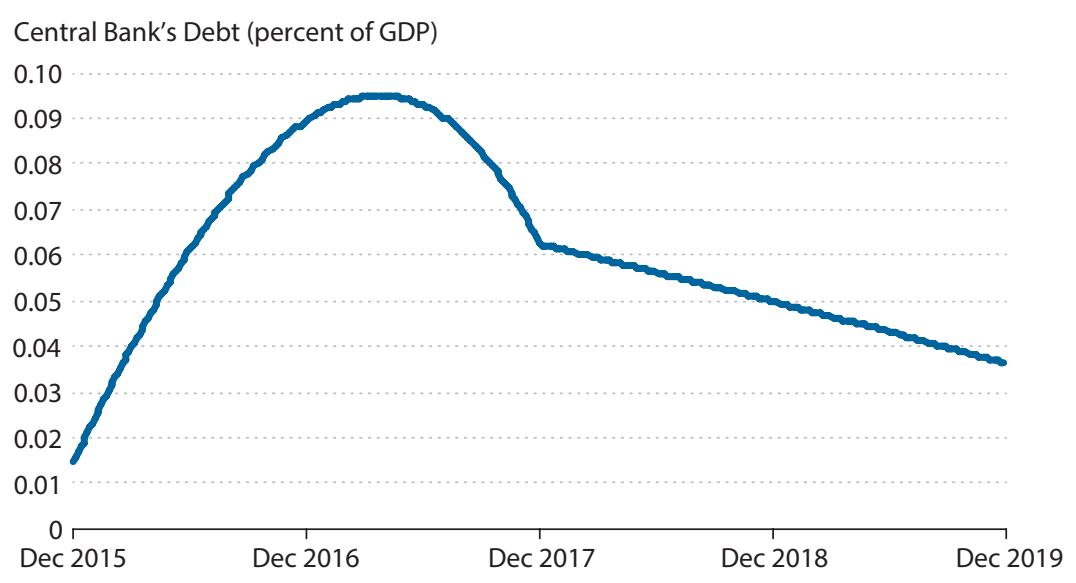

SOURCE: Authors' calculations.

\section{Figure A2}

\section{Weak Time Consistency: Debt-to-GDP Ratio}

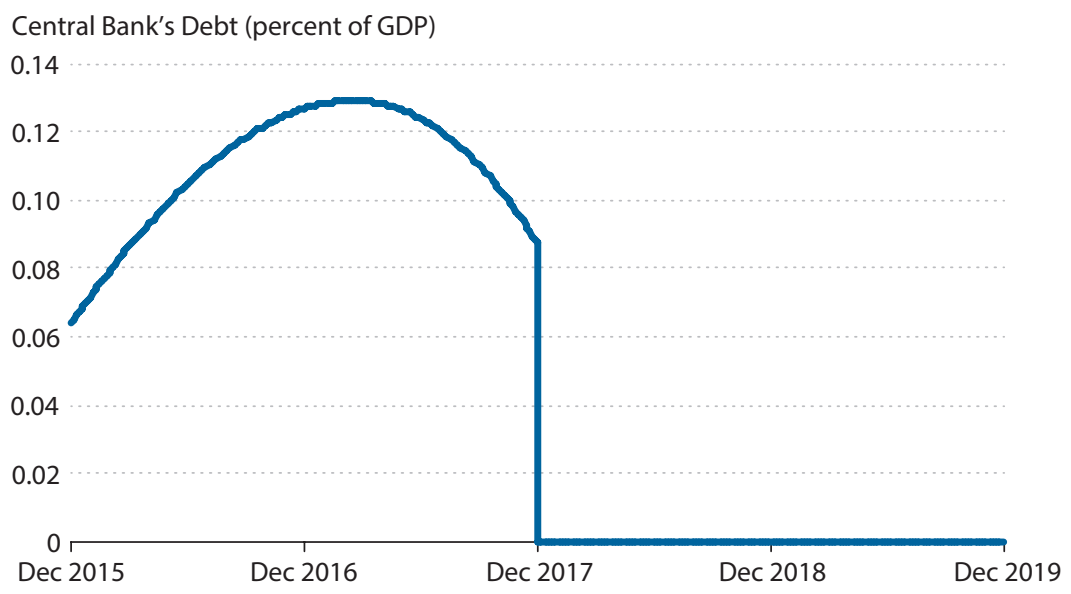

SOURCE: Authors' calculations. 


\section{NOTES}

1 It is impossible to determine why, if issuing bonds is part of the optimal policy, the fiscal authority chooses to delegate this to the monetary authority. The first-best optimal policy is one in which the mix of all taxes-including the inflation tax-is pinned down and the consolidated government budget constraint determines the evolution of the public debt. The analysis of the institutional arrangements that give rise to this situation is beyond the scope of this article.

$\underline{2}$ The Federal Reserve System also issues a bill-like security because reserves earn interest. However, these securities are like callable bonds because the holders can turn them into money on demand.

3 Nyawata (2012, Table 2) includes data on maximal maturities. In some cases, the upper bound is very long. Thailand's central bank can issue 20-year bonds, while the Armenian monetary authority can issue 15-year bonds.

4 Gray and Pongsaparn (2015) cite the case of the central bank of Chile, which in the early 1980s issued a large amount of debt to sterilize increases in the money supply associated with bailouts of domestic banks. Stella and Lonnberg (2008) provide other examples.

5 See Bassetto and Messer (2013) and Berriel and Bhattarai (2009) for examples of analyses that distinguish between the two budget constraints to keep track of monetary and fiscal interactions.

6 Effectively we are consolidating households and the non-governmental private sector. Thus, we view $m_{t}$ as the real value of the monetary base, including the portion held by commercial banks.

7 The original in Spanish is "El banco tiene por finalidad promover, en la medida de sus facultades y en el marco de las políticas establecidas por el gobierno nacional, la estabilidad monetaria, la estabilidad financiera, el empleo y el desarrollo económico con equidad social."

8 Even though by statute the president's mandate lasts six years, the median duration of a mandate over the past 30 years has been less than 9 months. It has been standard for incoming Treasury ministers to choose their own BCRA president. In many cases in which the BCRA president's and the Treasury's positions do not agree, the conflict is solved by the removal of the authorities of the BCRA. For example, in 2012 the BCRA president was removed after he refused to use international reserves to honor debts.

9 The law allows for doubling of the limits when economic conditions warrant such a change. This flexibility has been used in the recent past.

10 For example, the government of Honduras transferred a bond that, in nominal terms, increased the capital of the central bank by 1.1 percent of GDP in 1997. However, Stella and Lonnberg (2008) estimate that the market value of that bond was 0.0006 percent of GDP.

11 See BCRA (2016 or the most recent version) for more information about the current conduct of monetary policy in Argentina.

12 Seigniorage is computed as the year-over-year difference in the monetary base relative to the average nominal GDP in those 12 months. Inflation is measured as the 12-month average of the month-over-month inflation rate over the same period.

13 The Laffer curve shows the relationship between tax rates (inflation) and the amount of tax revenue (seigniorage) collected by governments. Traditionally, it exhibits an inverse u-shaped pattern.

14 The value for the first quarter of 2016 is somewhat misleading, as the new government eliminated some price controls that resulted in measured prices - those entering the price index — catching up to market-clearing prices.

15 Taking into account transfers to the Treasury only, the BCRA transferred to the Treasury the equivalent of 2.0 percent of GDP in 2016 and has committed to transfer 1.5 percent of GDP in 2017. 16 We experimented with a formulation that has a minimum level of money balances given by $v(m)=z \frac{(m y+v y)^{1-\gamma}}{1-\gamma}$,
but the estimate of $v$ was not significant.

17 In May 2016, the BCRA announced an increase in the mandatory reserve requirements of the financial system that roughly corresponds to a 4 percent increase in the demand for money, which in our case corresponds to a 12 percent increase in $K$. 


\section{Manuelli and Vizcaino}

18 Using monthly data requires a monthly measure of private consumption and GDP. We construct these series by performing a cubic spline interpolation of their quarterly counterparts.

19 The appendix describes the estimation procedure.

20 In the appendix, we report the results of several recent studies of the demand for money in Argentina.

21 The BCRA also inherited another liability in the form of underpriced exchange rate futures. Thus, our estimate is probably an understatement of the true initial cost.

22 As mentioned before, the previous administration used a significant portion of the foreign exchange reserves to fund Treasury operations. Thus, we assume that the increase in reserves brings them to the level that the BCRA considers adequate. Since the domestic real interest rate in Argentina is significantly higher than the return on its foreign currency holdings, we ignore this source of income and take the buildup of reserves as akin to an expenditure that earns no return and, hence, is part of $P_{t} x_{t}$.

$\underline{23}$ This implies that, in the last two years of the program, the average annual deficit is 0.6 percent and 0.1 percent of GDP, respectively, which is probably on the low end.

24 The latest available version of the BCRA's Market Expectations Survey (REM) corresponds to January 2017.

25 It does not appear that Uribe takes into account in his calculations the expenditures associated with the purchase of foreign reserves.

$\underline{26}$ The results of the model have to be taken as an approximation. There are at least two dimensions that can account for the difference in forecasts. First, the path of the deficit relative to GDP is best viewed as random. Second, the BCRA has indicated that the long-run inflation rate is 5 percent, rather than zero as we assumed.

27 In the past few years, the Fed has made substantial transfers to the Treasury as a result of the profits associated with the management of its portfolio. However, these were not legally mandated transfers and it is unclear to us what would happen if the Fed starts incurring losses on its portfolio.

28 In the extreme case of losses in its asset portfolio, the Fed can choose to pay no interest on reserves and, hence, cannot technically be required to increase the money supply in response to developments in its portfolio.

\section{REFERENCES}

Auernheimer, L. "The Honest Government's Guide to the Revenue from the Creation of Money." Journal of Political Economy, 1974, 82(3), pp. 598-606; https://doi.org/10.1086/260216.

Banco Central de la República Argentina (Central Bank of Argentina). Charter of the Central Bank of the Argentine Republic. N.d.; http://www.bcra.gov.ar/Pdfs/Institucional/CartaOrganica2012 i.pdf.

Banco Central de la República Argentina (Central Bank of Argentina). Informe de Objetivos y Planes respecto del desarrollo de la política monetaria, cambiaria, financiera y crediticia para el año 2017 (Annual Targets and Programs Report of the Central Bank of Argentina, 2017). December 2016, pp. 9-12.

Barro, Robert J. "On the Determination of the Public Debt." Journal of Political Economy, 1979, 87(6), pp. 940-71; https://doi.org/10.1086/260807.

Basco, E.; D'Amato, L. and Garegnani, L. "The Information Value of Money for Forecasting Purposes: The Cases of Argentina and Chile." Working Paper, Central Bank of Argentina, 2012.

Bassetto, M. and Messer, T. "Fiscal Consequences of Paying Interest on Reserves." Fiscal Studies, 2013, 34(4), pp. 413-36; https://doi.org/10.1111/j.1475-5890.2013.12014.x.

Berriel, T. and Bhattarai, S. "Monetary Policy and Central Bank Balance Sheet Concerns." B.E. Journal of Macroeconomics, 2009, 9(1), pp. 1-31; https://doi.org/10.2202/1935-1690.1770.

Burdisso, T.; Blanco, E. and Sardi, M. "Seasonal Adjustment and Local Calendar Effects in Argentina's Monetary Aggregate." Central Bank of Argentina Ensayos Económicos, June 2010.

Canzoneri, M.; Cumby, R. and Diba, B. "The Interaction Between Monetary and Fiscal Policy," in B.M. Friedman and M. Woodford, eds., Handbook of Monetary Economics. Volume 3B. The Netherlands: North-Holland, 2011, pp. 935-99. 
Cao, Q. “Optimal Fiscal and Monetary Policy with Collateral Constraints." Working paper, 2017.

Del Negro, M. and Sims, C. "When Does a Central Bank's Balance Sheet Require Fiscal Support?" Staff Report No. 701, Federal Reserve Bank of New York, 2015.

Díaz-Giménez, J.; Giovannetti, G.; Marimon, R. and Teles, P. "Nominal Debt as a Burden on Monetary Policy." Review of Economic Dynamics, 2008, 11(3), pp. 493-514; https://doi.org/10.1016/j.red.2007.11.002.

Gay, A. "Money Demand in an Open Economy Framework: Argentina (1932-2002)." Working paper, Universidad Nacional de La Plata, 2005.

Gray, S. and Pongsaparn, R. "Issuance of Central Bank Securities: International Experiences and Guidelines." IMF Working Paper WP/15/106, International Monetary Fund, 2015.

Kiguel, M. and Neumeyer, P. "Seignorage and Inflation: The Case of Argentina." Journal of Money Credit and Banking, 1995, 27(3), pp. 672-82; https://doi.org/10.2307/2077742.

Leeper, E.; Campbell, L. and Ding, L. “Optimal Time-Consistent Monetary, Fiscal and Debt Maturity Policy." Working paper, 2016.

Lucas, R. Jr. and Nicolini, J. "On the Stability of Money Demand." 2013 Meeting Papers 353, Society for Economic Dynamics, 2013.

Lucas, R. Jr. and Stokey, N.L. "Optimal Fiscal and Monetary Policy in an Economy Without Capital." Journal of Monetary Economics, 1983, 12(1), pp. 55-93; https://doi.org/10.1016/0304-3932(83)90049-1.

Martin, F. “Government Policy in Monetary Economies." International Economic Review, 2013, 54(1), pp. 185-217; https://doi.org/10.1111/j.1468-2354.2012.00730.x.

Mogliani, M.; Urga, G. and Winograd, C. "Monetary Disorder and Financial Regimes. The Demand for Money in Argentina, 1900-2006." Working paper, 2009.

Nyawata, O. "Treasury Bills and/or Central Bank Bills for Absorbing Surplus Liquidity: The Main Considerations." IMF working paper WP/12/40, International Monetary Fund, 2012.

Sargent, T. and Wallace, N. "Some Unpleasant Monetarist Arithmetic." Federal Reserve Bank of Minneapolis Quarterly Review, Fall 1981, pp. 1-17; https://www.minneapolisfed.org/research/quarterly-review/some-unpleasant-monetarist-arithmetic.

Stella, P. and Lonnberg, A. "Issues in Central Bank Finance and Independence." IMF Working Paper WP/08/37, International Monetary Fund, 2008.

Uribe, M. "Is the Monetarist Arithmetic Unpleasant?" NBER Working Paper 22866, National Bureau of Economic Research, 2016. 
